\title{
Stabilization of Rice Bran in Broiler Feed with Natural and Synthetic Antioxidants and Heat Treatment
}

http://dx.doi.org/10.1590/1806-9061-2019-1062

\section{-Author(s)}

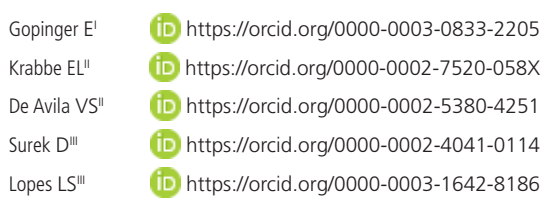

Postdoctoral researcher at $\mathrm{CNPq}$ Brasil (313576/2015-7), zip code 89700-000, Concordia, Santa Catarina, Brazil.

" Researcher at Embrapa Swine and Poultry, zip code 89700-000, Concordia, Santa Catarina, Brazil.

Analyst at Embrapa Swine and Poultry, zip code 89700-000, Concordia, Santa Catarina, Brazil.

\section{-Mail Address}

Corresponding author e-mail address Edenilse Gopinger

Postdoctoral researcher at CNPq Brasil, Rodovia BR-153, Km 110, Distrito de Tamanduá Caixa Postal: 321, Concórdia, 89715-899, SC, Brazil.

Phone: +55 4934440400

Email: edezoo@yahoo.com.br

\section{- Keywords}

Alternative feedstuff, Meat quality, Poultry, Oxidation, Digestibility.

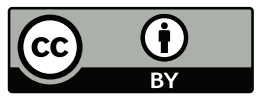

Submitted: 04/April/2019

Approved: 29/July/2019

\section{ABSTRACT}

The objective of this study was to evaluate different strategies for the oxidative stabilization of rice bran (RB) in the diet of broiler chickens using natural antioxidant additives, synthetic antioxidant additives and heat treatment on performance, breast meat quality and liver fat content and the nutrient digestibility coefficients. Furthermore, the study aimed to evaluate the effects of heat treatment and antioxidants, antioxidant additive treatments, without antioxidants, natural, and synthetic, and to three heat treatments, without heat, dry-heat and moist-heat, after the rice bran was stored for 90 days and then incorporated into the experimental diets. 1080 broilers were arranged in a $3 \times 3$-factorial randomized design with 10 replicates per treatments. The wet heat treatment of the meal resulted in a higher daily feed intake and body weight at 28 days and better feed conversion than did the meal without heat treatment. No significant interactions were observed between the tested factors on the apparent digestibility of dry matter and ether extract as well as the values of apparent metabolizable energy and apparent metabolizable energy corrected for nitrogen. However, there was significant interaction between the tested factors on the nitrogen retention coefficient; the natural antioxidant and dry heattreated meal combination presented a lower crude protein digestibility coefficient than those without heat treatment. In conclusion, thermal treatment of this bran proved to be more effective as demonstrated by the performance responses of the birds. Broiler chickens reared up to 28 days of age consuming diets containing $6.5 \%$ RB stabilized by heat treatment showed better performance, and the use of antioxidants was not necessary.

\section{INTRODUCTION}

Rice bran (RB) is a by-product of rice processing that consists of pericarp, germ, rice fragments and small amounts of rice hulls, with an oil content of approximately $18 \%$. However, this raw material has low commercial value due to problems with oxidative stability, which poses a challenge to the production of foods with acceptable quality and taste (Glushenkova et al., 1998).

In addition, RB presents lipolytic enzymes that favour the development of rancidity and make it very unstable during storage (Mujahid et al., 2003). The fatty acids released by the hydrolysis of triglycerides during storage produce acid and an unpleasant taste and cause nutrient deterioration, which compromises the use of RB in animal feed (Pestana et al., 2009).

In this context, some researchers have reported the need for RB to be stabilized shortly after its production, with the aim of reducing the activity of enzymes, mainly lipases, peroxides and lipoxygenases 
(Brunschwiler et al., 2013). Heating has been shown to be the most effective method for lipase inactivation and stable RB production without increasing free fatty acids during storage (Mujahid et al., 2003; Oliveira et al., 2012). Microwave heating processes have specific characteristics, such as the instantaneous penetration of the product and the rapid conversion of electromagnetic energy to heat. Furthermore, they reduce treatment times and have unique technological features since they uniformly heat the material, thus optimizing processing and product quality (Rocha, 2002).

Besides that, antioxidants retard the oxidative spoilage while light, air and high temperature accelerate spoilage process. In the presence of oxygen, light, heat or metals, unsaturated fatty acids are converted to fatty acid radicals which undergo further reduction, to produce more free radicals or peroxides which in turn act on fatty acids. Antioxidants inhibit oxidation by reacting with free radicals, which are formed early in oxidation process, blocking the formation of fatty acid radicals and terminate the chain reaction (Waheed et al., 2004).

Many natural and synthetic antioxidants have shown a decrease or delay in the undesirable evidence of oxidation progress. There are many studies showing that feeding poultry with antioxidant compounds added into the diets containing antioxidants improve the oxidative stability (Luna et al., 2010; Karre et al., 2013; Haselmeyer et al., 2015).

All these potential benefits coupled with changes in some countriescountry's regulations on the use of synthetic compounds in animal nutrition have stimulated the interest for further research in the use and potential effects of phytochemicals in the diets of farmed animals. Furthermore, studies on butylated hydroxytoluene (BHT), a widely used synthetic antioxidant compound, have shown potential toxicity and adverse effects (Carocho \& Ferreira, 2013). It has been demonstrated that herbs and spices are compounds that, when included into animal diets, are generally effective to help sustain good health, performance, welfare of the animals, and the oxidative stability of their products (Amad et al., 2011; Borazjanizadeh et al., 2011; Hafeez et al., 2016).

Another RB stabilization technology is pelletizing through mechanical processes combined with humidity, pressure and heat. This treatment uses mild temperature and pressure and thus requires a longer processing time. Furthermore, the use of natural and synthetic antioxidant additives may delay oxidative deterioration (Waheed et al., 2004).
In this context, the objective of the present study was to evaluate the stabilization of brown RB with natural and synthetic antioxidants and with dry-heat and moist-heat treatment and its inclusion at $6.5 \%$ of the diet on broiler performance, liver and breast yield, breast meat quality, nutrient digestibility and energy metabolization.

\section{MATERIAL AND METHODS}

The methodology and protocols for this experiment were approved by the Ethics Committee on the Use of Animals of the Brazilian Agricultural Research Corporation under protocol number 012/2014.

\section{Animals, Experimental Design and Diets}

A total of 1080 one-day-old male Cobb broilers were housed in metal batteries with grated floors in a completely randomized design. A $3 \times 3$ factorial arrangement of treatments (thermal treatment $x$ antioxidant) was applied with ten replicates for 90 experimental units with each cage being an experimental unit composed of 12 birds.

Prior to the storage, the RB was submitted to three antioxidant additive treatments, without antioxidants, natural, and synthetic, and to three heat treatments, without heat, dry-heat and moist-heat, to prevent rancidity and/or oxidation and then stored. The natural antioxidant (1000 ppm tocopherols, $250 \mathrm{ppm}$ citric acid and 1000 ppm neem oil), and all rice bran were stored on a wooden pallet in the dark in a covered, dry, wellventilated place for 90 days, and the synthetic antioxidant consisted of $100 \mathrm{ppm}$ TBHQ (Tertiary Butylhydroquinone), $250 \mathrm{ppm}$ citric acid, and 5000 ppm formaldehyde. The evaluated thermal treatments were conducted as follows: without heat exposure; thermal stabilization with dry-heat (with a 1000-W microwave intermittently for 4 min at an average temperature of $85^{\circ} \mathrm{C}$ ) and moistheat (conditioning at $90^{\circ} \mathrm{C}$ for approximately 10 seconds followed by $4.75-\mathrm{mm}$ matrix pelletization). This resulted in a $3 \times 3$ factorial arrangement of treatments consisting of natural or synthetic antioxidants and without antioxidant combined with dry-heat, moist-heat and without heat.

Experimental diets were mash and formulated to meet the nutritional requirements (regular performance) of the birds according to the recommendations of Rostagno et al. (2011) (Table 1), and rice bran (RB) was included as $6.5 \%$ of the diets. 
Table 1 - Composition of experimental diets $(\mathrm{g} / \mathrm{kg})$.

\begin{tabular}{|c|c|}
\hline Ingredients & $\mathrm{g} / \mathrm{kg}$ \\
\hline Maize $(7.5 \% \mathrm{CP})$ & 505.5 \\
\hline Soya bean meal ( $45 \%$ CP) & 360.7 \\
\hline Rice bran & 65.0 \\
\hline Soya bean oil & 29.2 \\
\hline Kaolin & 1.00 \\
\hline Dicalcium phosphate ${ }^{1}$ & 13.8 \\
\hline Limestone $^{2}$ & 10.0 \\
\hline Salt & 5.00 \\
\hline DL-Methionine & 2.70 \\
\hline L-Lysine $\mathrm{HCl}$ & 2.20 \\
\hline Vitamin $\operatorname{mix}^{3}$ & 1.00 \\
\hline Mineral mix ${ }^{4}$ & 0.50 \\
\hline L-Threonine & 0.90 \\
\hline Choline chloride & 0.60 \\
\hline BHT & 0.10 \\
\hline Toxin sequestrant & 1.80 \\
\hline \multicolumn{2}{|l|}{ Calculated composition } \\
\hline $\mathrm{ME}(\mathrm{MJ} / \mathrm{kg})$ & 12.35 \\
\hline Crude Protein & 210.5 \\
\hline Calcium & 8.20 \\
\hline Available phosphorus & 3.90 \\
\hline Sodium & 2.10 \\
\hline Digestible Lysine & 11.70 \\
\hline Digestible Methionine & 5.40 \\
\hline Digestible Methionine + cystine & 8.40 \\
\hline \multicolumn{2}{|l|}{ Analysed composition } \\
\hline Ash & 57.7 \\
\hline Crude protein & 227.0 \\
\hline Ether Extract & 65.2 \\
\hline Crude Energy (MJ/kg) & 17.22 \\
\hline
\end{tabular}

${ }^{1}$ Calcium: minimum $210 \mathrm{~g} / \mathrm{kg}$, maximum 250g / kg; Phosphorus: $180 \mathrm{~g} / \mathrm{kg} ;{ }^{2}$ Calcium: minimum 33\%; ${ }^{3}$ levels per kg of product: Retinol: $2700 \mathrm{mg}$, cholecalciferol: $62.5 \mathrm{mg}$, tocopherol: 20000 mg, menadione: 2500 mg, thiamin: 1500 mg, Riboflavin: 6000 mg, Pyridoxine: 3000 mg, Cobalamin: 12000 mcg, Pantothenic acid: 12g, Niacin: 25g, Folic acid: $800 \mathrm{mg}$, Biotin: $60 \mathrm{mg}$, Selenium: $250 \mathrm{mg} .{ }^{4}$ levels per kg of product: Copper: 20g, Iron: 100g, Manganese: 160g, Cobalt: 2000 mg, lodine: 2000 mg, Zinc: 100g.

\section{Growth performance}

The following performance variables were evaluated: average body weight of the birds, daily weight gain, feed intake and feed conversion. The birds were weighed on the first day of the experiment and then weekly throughout the experimental period (1 to 28 days of age). The amount of feed was also weighed throughout the experimental period

\section{Meat quality and liver composition}

At the end of the experimental period (28 days of age), two birds per replicate, totalling 20 birds per treatment, were identified, weighed and slaughtered by cervical dislocation to measure the weight of the breast meat and liver to determine the yield in relation to live weight. The breast meats and livers were frozen at $-10^{\circ} \mathrm{C}$ for subsequent evaluations.
To quantify the breast meat quality parameters, the meat samples were thawed under refrigeration (3 to $\left.5^{\circ} \mathrm{C}\right)$ for 24 hours, and $100 \mathrm{~g}$ of each sample $( \pm 5.0$ g) were weighed and packed in a sturdy plastic bag to avoid contact with the external environment and kept fully submerged in a water bath during cooking at a controlled temperature of $70-75^{\circ} \mathrm{C}$ for one hour. After this period, the samples were removed from the bath and the packages and placed on a paper towel until they reached room temperature. They were then weighed again to determine the loss by cooking (LC) (Honikel, 1987), which was determined by calculating the difference between the initial and final weights. After the samples were cut towards the muscle fibres into approximately $1.0 \mathrm{~cm} \times 1.0 \mathrm{~cm} \times$ $2.5 \mathrm{~cm}$ rectangles, they were analysed with a texture analyser (TA XT Plus Texture Analyzer ${ }^{\odot}$, Texture Technologies Corporation), and the shear force (kgf) was determined. Drip water loss (LW) was analysed using the technique described by Boccard et al. (1981) using samples of the pectoralis major muscle, which was removed from the carcass and cooled for 24 hours at $2 \pm 1^{\circ} \mathrm{C}$. Each sample had a thickness of approximately $2.0 \mathrm{~cm}$ after removing the bone and adipose tissues and the most superficial layer, thus avoiding the use of tissue that had been dehydrated by contact with the air. The samples were weighed in a semi-analytical balance and conditioned in a dripspecific collector. After the samples were refrigerated for 48 hours at $4^{\circ} \mathrm{C}$, they were removed from the refrigerator, and contact with the liquid exuded by the meat was avoided. The samples were gently dried with a paper towel and weighed again, which allowed the percentage of water loss per drip (\%) to be calculated using the formula [100 - (Final sample weight $x$ 100) / (Initial sample weight)].

Colour evaluation was performed using a Chroma Meter CR-310 colorimeter (Minolta, Osaska, Japan) and the $L *, a *, b$ * system, where $L$ * is luminosity, $a *$ is the intensity of the colour red and $b *$ is the intensity of the colour yellow. Three distinct points of the pectoralis major muscle were analysed, and the values were used to obtain an average colour for this muscle.

Liver samples were lyophilized, and the fat content was determined following the method 30-20 from the American Association of Cereal Chemists (AACC, 1995).

\section{Nutrient digestibility}

To evaluate the nutrient digestibility coefficient, excreta were collected (Sakomura \& Rostagno, 2007) 
from 19 to 22 days of age while the birds were kept in metal batteries with grated metallic floors over collecting trays. The excreta were collected once a day per experimental unit (the feathers and the rest of the rations of the trays were removed) and packed and frozen $\left(-10^{\circ} \mathrm{C}\right)$ to avoid fermentation of the samples. During the same period, the amount of feed consumed and the total excreta produced were determined. At the end of the collection period, the excreta were thawed and homogenized and then pre-dried in a forced-air ventilation oven at $55^{\circ} \mathrm{C}$ for 72 hours, and both the excreta and feed samples were analysed for dry matter (DM), nitrogen retention (NR), ether extract (EE) and gross energy (CE) contents in a calorimeter pump (LECO AC500). To analyses, the DM was determined using a drying oven at $105 \pm 3^{\circ} \mathrm{C}$ with natural air circulation for $24 \mathrm{~h}$ following recommendations from the American Society of Agricultural Engineers (ASAE, 2000); the content was expressed as percentage (\%). The ether extract was determined following the method 30-20 from the American Association of Cereal Chemists (AACC, 1995). The nitrogen content was determined using the AACC method 46-13 (Ibid.), and the protein content was determined using a 6.25 nitrogen to protein conversion factor. With the results obtained from the laboratory analyses of the rations and excreta, the apparent metabolizable energy (AME) and apparent metabolizable energy corrected for nitrogen (AMEn) values were calculated according to the equations: $A M E=[(G E c-G E e x) / D M c]$, where $G E c=$ gross energy consumed, GEex= gross energy excreted and $\mathrm{DMc}=$ Dry matter consumed. And AMEn $=[\mathrm{GEC}$ - GEex - (8.22*NB)/ DMc], where GEc= gross energy consumed, GEex= gross energy excreted, DMc $=$ Dry matter consumed and $\mathrm{NB}=$ nitrogen balance (nitrogen consumed - nitrogen excreted) proposed by Matterson et al. (1965). The apparent nutrient digestibility coefficients (ADC) for DM, NR, and EE were determined using the formula: $A D C(\%)=[(N C-N E x) / N C] \times 100$, where $N C$ = the amount of nutrients consumed, and NEx = the amount of nutrients excreted according to the methodology proposed by Sakomura and Rostagno (2007).

\section{Statistical Analysis}

The data were analyzed using GLMs in the SAS program (SAS Inst., Inc., Cary, NC, 2002). The data were subjected to analysis of variance (ANOVA) with a $3 \times 3$ factorial, such model is a very powerful way to examine interactions to evaluate the interactions between the antioxidants and the heat treatments. In case of significant interactions, the data was analyzed with one-way anova. When there were no significant interactions, the effects of the antioxidant types and the heat treatments were analysed separately by Tukey's test at a 5\% level of significance.

\section{RESULTS}

The performance data are presented in table 2 . There was no interaction between the factors for the variables of daily weight gain, body weight at 28 days and feed conversion ( $p>0.05$ ). When separately evaluating the antioxidants, there was no significant effect of the antioxidant type on the performance variables. However, the moist heat treatment of the RB resulted in a higher daily feed intake and body weight at 28 days and better feed conversion compared to the RB without heat treatment.

There was a significant interaction between antioxidants and thermal treatment on the daily feed intake (Table 2); the dry-heat treatment lowered feed intake compared to the humid heat treatment (Table 3). In the humid heat treatment, the use of a synthetic antioxidant resulted in a higher daily feed intake compared with the natural antioxidant and the control.

The breast and liver weight and yield results are presented in table 4, and no significant interactions were observed between the factors. Additionally, the antioxidant type and heat treatment has no significant effect on these variables. In relation to the breast meat quality (Table 5) and the fat content of the liver (Table 6), no significant interaction in factorial was observed between the tested factors, nor was there an isolated effect of the use of supplemental antioxidants and heat treatment of RB on drip loss, cooking loss, shear force, breast colour and liver composition.

Table 7 shows the nutrient digestibility coefficient data, and there were no significant effects of the interactions between the tested factors on the coefficient of apparent digestibility of dry matter and ether extract.

The apparent metabolizable energy and the nitrogen-corrected apparent metabolizable energy of the diets were also not affected by the RB treatments, nor were the heat treatments and antioxidants significantly affected by the nutrient digestibility $A D C$ and ADC EEE coefficients. Similarly, Pasha et al. (2008) evaluated the effects of adding RB kept under different storage times and with different antioxidants to the poultry diet and found no differences in apparent and true metabolizable energy. However, there was a significant interaction between the factors on the nitrogen retention coefficient (Table 7). The natural 
antioxidant meal treated with dry-heat showed a lower nitrogen retention coefficient than the diets without heat treatment (Table 8), the natural antioxidant resulted in a lower protein digestibility coefficient than the synthetic antioxidant treatment. However, when the meal was treated with humid heat, the synthetic antioxidant presented a lower digestibility coefficient than the control without an antioxidant.

Table 2 - Performance ( 1 up to 28 days age) of broilers fed diets containing $6.5 \%$ rice bran stored for 90 days, with antioxidant additives and heat treatment (mean \pm standard deviation).

\begin{tabular}{|c|c|c|c|c|c|c|}
\hline & & Body weight Starter (g) & Daily feed intake (g) & Daily weight gain (g) & Body weight 28 days (g) & Feed conversion (g:g) \\
\hline & Without & $42.06 \pm 2.67$ & $67.70 \pm 3.77$ & $47.38 \pm 3.67$ & $1368.73 \pm 103.12$ & $1.434 \pm 0.09$ \\
\hline \multirow[t]{3}{*}{ Antioxidant } & Natural & $42.13 \pm 2.68$ & $67.10 \pm 3.17$ & $47.25 \pm 3.46$ & $1365.40 \pm 97.45$ & $1.424 \pm 0.08$ \\
\hline & Synthetic & $42.06 \pm 2.70$ & $68.00 \pm 5.15$ & $47.00 \pm 3.52$ & $1358.24 \pm 99.09$ & $1.449 \pm 0.08$ \\
\hline & Without & $42.09 \pm 2.73$ & $67.57 \pm 4.22$ & $46.23 \pm 4.11 b$ & $1336.74 \pm 115.15 b$ & $1.467 \pm 0.09 \mathrm{a}$ \\
\hline \multirow[t]{2}{*}{ Heat Treatment } & Dry & $42.11 \pm 2.64$ & $67.03 \pm 3.89$ & $46.95 \pm 3.60 a b$ & $1356.74 \pm 101.75 a b$ & $1.431 \pm 0.06 \mathrm{ab}$ \\
\hline & Moist & $42.05 \pm 2.67$ & $68.20 \pm 4.19$ & $48.45 \pm 2.32 \mathrm{a}$ & $1398.90 \pm 65.81 \mathrm{a}$ & $1.409 \pm 0.09 b$ \\
\hline \multicolumn{7}{|l|}{$p$ values* } \\
\hline \multicolumn{2}{|l|}{ Antioxidant } & 0.99 & 0.66 & 0.91 & 0.91 & 0.54 \\
\hline \multicolumn{2}{|l|}{ Heat Treatment } & 0.99 & 0.52 & 0.04 & 0.04 & 0.04 \\
\hline \multicolumn{2}{|c|}{ Antioxidant X Heat Treatment } & 1.00 & 0.02 & 0.58 & 0.59 & 0.30 \\
\hline
\end{tabular}

$p^{*}$ significance level at $5 \%$ by ANOVA. Means followed by distinct letters in the column differ significantly by the Tukey test $(p \leq 0.05)$ within each factor. Natural antioxidant ( 1000 ppm tocopherols, 250 ppm citric acid and 1000 ppm neem oil); synthetic antioxidant (100 ppm TBHQ (Tertiary Butylhydroquinone), 250 ppm citric acid, and 5000 ppm formaldehyde; dry-heat (with a 1000-W microwave intermittently for $4 \mathrm{~min}$ at an average temperature of $85^{\circ} \mathrm{C}$ ) and moist-heat (conditioning at $90^{\circ} \mathrm{C}$ for approximately 10 seconds followed by 4.75-mm matrix pelletization).

Table 3 - Factor interaction for the daily feed intake of broiler ration from 1 to 28 days of age (mean \pm standard deviation).

\begin{tabular}{lccc}
\hline & \multicolumn{3}{c}{ Daily feed intake $(\mathrm{g})$} \\
\cline { 2 - 4 } Heat Treatment & Without & Antioxidant & Synthetic \\
\cline { 2 - 4 } & $68.67 \pm 4.96$ & $67.23 \pm 2.80$ & $66.81 \pm 4.79 \mathrm{AB}$ \\
Without & $67.89 \pm 3.87$ & $67.48 \pm 4.46$ & $65.73 \pm 3.33 \mathrm{~B}$ \\
Mry & $66.56 \pm 1.93 \mathrm{~b}$ & $66.58 \pm 2.04 \mathrm{~b}$ & $71.46 \pm 5.57 \mathrm{Aa}$ \\
\hline
\end{tabular}

Capital letters in the column differ from each other depending on the heat treatment within each antioxidant. Lowercase letters on the line differ from each other depending on the antioxidant within each heat treatment. Natural antioxidant (1000 ppm tocopherols, 250 ppm citric acid and 1000 ppm neem oil); synthetic antioxidant (100 ppm TBHQ (Tertiary Butylhydroquinone), $250 \mathrm{ppm}$ citric acid, and $5000 \mathrm{ppm}$ formaldehyde; dry-heat (with a 1000-W microwave intermittently for 4 min at an average temperature of $85^{\circ} \mathrm{C}$ ) and moistheat (conditioning at $90^{\circ} \mathrm{C}$ for approximately 10 seconds followed by 4.75 -mm matrix pelletization).

Table 4 - Breast and liver weight and yield of broiler chickens (28 days) fed with diets containing $6.5 \%$ rice bran stored for 90 days, with antioxidant additives and heat treatment (mean \pm standard deviation).

\begin{tabular}{|c|c|c|c|c|c|c|}
\hline & & Body weight (g) & Breast weight (g) & Liver weight (g) & Breast yield (\%) & Liver Yield (\%) \\
\hline & Without & $1471.91 \pm 118.75$ & $338.50 \pm 29.77$ & $32.13 \pm 3.96$ & $22.99 \pm 1.08$ & $2.17 \pm 0.18$ \\
\hline \multirow[t]{3}{*}{ Antioxidant } & Natural & $1469.75 \pm 116.25$ & $338.76 \pm 41.10$ & $33.08 \pm 3.34$ & $22.98 \pm 1.48$ & $2.25 \pm 0.16$ \\
\hline & Synthetic & $1446.08 \pm 119.45$ & $331.73 \pm 39.40$ & $31.90 \pm 3.08$ & $22.88 \pm 1.34$ & $2.21 \pm 0.18$ \\
\hline & Without & $1455.91 \pm 128.14$ & $337.08 \pm 42.73$ & $31.83 \pm 3.76$ & $23.07 \pm 1.49$ & $2.18 \pm 0.19$ \\
\hline \multirow[t]{2}{*}{ Heat treatment } & Dry & $1457.50 \pm 123.54$ & $334.40 \pm 37.95$ & $32.85 \pm 3.54$ & $22.91 \pm 1.37$ & $2.25 \pm 0.16$ \\
\hline & Moist & $1474.33 \pm 102.05$ & $337.51 \pm 29.79$ & $32.43 \pm 3.16$ & $22.87 \pm 1.01$ & $2.19 \pm 0.17$ \\
\hline \multicolumn{7}{|l|}{$p$ values* } \\
\hline \multicolumn{2}{|l|}{ Antioxidant } & 0.65 & 0.71 & 0.39 & 0.94 & 0.25 \\
\hline \multicolumn{2}{|l|}{ Heat Treatment } & 0.80 & 0.94 & 0.53 & 0.82 & 0.31 \\
\hline \multicolumn{2}{|c|}{ Antioxidant X Heat Treatment } & 0.74 & 0.74 & 0.77 & 0.65 & 0.29 \\
\hline
\end{tabular}

$p^{*}$ significance level at $5 \%$ by ANOVA. Means followed by distinct letters in the column differ significantly by the Tukey test $(p \leq 0.05)$ within each factor. Natural antioxidant (1000 ppm tocopherols, 250 ppm citric acid and 1000 ppm neem oil); synthetic antioxidant (100 ppm TBHQ (Tertiary Butylhydroquinone), 250 ppm citric acid, and 5000 ppm formaldehyde; dry-heat (with a 1000-W microwave intermittently for 4 min at an average temperature of $85^{\circ} \mathrm{C}$ ) and moist-heat (conditioning at $90^{\circ} \mathrm{C}$ for approximately 10 seconds followed by 4.75-mm matrix pelletization). 
Table 5 - Breast meat quality of broiler chickens (28 days) fed with diets containing $6.5 \%$ rice bran stored for 90 days, with antioxidant additives and heat treatment (mean \pm standard deviation).

\begin{tabular}{|c|c|c|c|c|c|c|c|}
\hline & & $\mathrm{LW}(\%)$ & LC (\%) & SF (kgf) & $L^{*}$ & $a^{*}$ & $b^{*}$ \\
\hline & Without & $1.01 \pm 0.32$ & $28.92 \pm 1.22$ & $2.01 \pm 0.59$ & $45.95 \pm 2.26$ & $1.66 \pm 0.70$ & $4.77 \pm 1.20$ \\
\hline \multirow[t]{3}{*}{ Antioxidant } & Natural & $0.87 \pm 0.46$ & $29.03 \pm 1.10$ & $2.00 \pm 0.55$ & $46.28 \pm 1.57$ & $1.50 \pm 0.77$ & $4.75 \pm 1.07$ \\
\hline & Synthetic & $1.00 \pm 0.46$ & $28.77 \pm 1.12$ & $1.91 \pm 0.56$ & $46.04 \pm 1.57$ & $1.41 \pm 0.80$ & $4.75 \pm 0.94$ \\
\hline & Without & $0.92 \pm 0.29$ & $29.00 \pm 1.07$ & $1.88 \pm 0.47$ & $46.11 \pm 1.28$ & $1.56 \pm 0.65$ & $4.71 \pm 1.17$ \\
\hline \multirow[t]{2}{*}{ Heat Treatment } & Dry & $1.00 \pm 0.45$ & $28.91 \pm 0.96$ & $1.99 \pm 0.52$ & $46.33 \pm 2.35$ & $1.55 \pm 0.81$ & $4.77 \pm 1.08$ \\
\hline & Humid & $0.96 \pm 0.50$ & $28.81 \pm 1.38$ & $2.06 \pm 0.68$ & $45.83 \pm 1.68$ & $1.47 \pm 0.81$ & $4.79 \pm 0.97$ \\
\hline \multicolumn{8}{|l|}{$p *$ values } \\
\hline \multicolumn{2}{|l|}{ Antioxidant } & 0.36 & 0.70 & 0.77 & 0.77 & 0.45 & 0.99 \\
\hline \multicolumn{2}{|l|}{ Heat Treatment } & 0.78 & 0.82 & 0.46 & 0.57 & 0.88 & 0.95 \\
\hline \multicolumn{2}{|c|}{ Antioxidant $X$ Heat treatment } & 0.93 & 0.78 & 0.75 & 0.34 & 0.81 & 0.08 \\
\hline
\end{tabular}

$p^{*}$ significance level at $5 \%$ by ANOVA. Means followed by distinct letters in the column differ significantly by the Tukey test $(p \leq 0.05)$ within each factor LW- loss of water by dripping; LC - loss by cooking; SF - shear force; L * luminosity; A * - intensity of red color; B * - intensity of the yellow color. Natural antioxidant (1000 ppm tocopherols, $250 \mathrm{ppm}$ citric acid and 1000 ppm neem oil); synthetic antioxidant (100 ppm TBHQ (Tertiary Butylhydroquinone), 250 ppm citric acid, and 5000 ppm formaldehyde; dry-heat (with a 1000-W microwave intermittently for $4 \mathrm{~min}$ at an average temperature of $85^{\circ} \mathrm{C}$ ) and moist-heat (conditioning at $90^{\circ} \mathrm{C}$ for approximately 10 seconds followed by 4.75 -mm matrix pelletization).

Table 6 - Effect of the use of antioxidant additives and heat treatment on the rice bran on the liver ether extract content of broilers at 28 days of age (mean \pm standard deviation).

\begin{tabular}{|c|c|c|c|c|}
\hline & & DM (\%) & EE NM (\%) & EE DM (\%) \\
\hline & Without & $26.03 \pm 0.98$ & $4.01 \pm 0.51$ & $15.39 \pm 1.67$ \\
\hline \multirow[t]{3}{*}{ Antioxidant } & Natural & $26.07 \pm 0.87$ & $4.05 \pm 0.51$ & $15.53 \pm 1.57$ \\
\hline & Synthetic & $26.40 \pm 1.10$ & $4.34 \pm 0.80$ & $16.35 \pm 2.35$ \\
\hline & Without & $26.22 \pm 1.06$ & $4.14 \pm 0.72$ & $15.73 \pm 2.16$ \\
\hline \multirow[t]{2}{*}{ Heat treatment } & Dry & $25.98 \pm 0.89$ & $3.96 \pm 0.54$ & $15.22 \pm 1.67$ \\
\hline & Moist & $26.31 \pm 1.02$ & $4.30 \pm 0.60$ & $16.32 \pm 1.80$ \\
\hline \multicolumn{5}{|l|}{$p^{*}$ values } \\
\hline Antioxidant & & 0.27 & 0.08 & 0.09 \\
\hline Heat Treatment & & 0.40 & 0.09 & 0.07 \\
\hline Antioxidant $X$ Heat Treatment & & 0.22 & 0.11 & 0.15 \\
\hline
\end{tabular}

$p^{*}$ significance level at $5 \%$ by ANOVA. Means followed by distinct letters in the column differ significantly by the Tukey test $(p \leq 0.05)$ within each factor. DM- Dry matter; EE- Ether extract; NM-natural matters. Natural antioxidant (1000 ppm tocopherols, 250 ppm citric acid and 1000 ppm neem oil); synthetic antioxidant (100 ppm TBHQ (Tertiary Butylhydroquinone), 250 ppm citric acid, and 5000 ppm formaldehyde; dry-heat (with a 1000-W microwave intermittently for 4 min at an average temperature of $85^{\circ} \mathrm{C}$ ) and moist-heat (conditioning at $90^{\circ} \mathrm{C}$ for approximately 10 seconds followed by $4.75-\mathrm{mm}$ matrix pelletization).

Table 7 - Apparent digestibility coefficient (ADC) and apparent metabolizable energy (AME) and apparent metabolizable energy corrected for nitrogen (AMEn) dry matter basis for broilers fed diets containing 6.5\% RB stored for 90 days with antioxidants and heat treatment (mean \pm standard deviation).

\begin{tabular}{|c|c|c|c|c|c|c|}
\hline & & ADC DM (\%) & ADC NR (\%) & ADC EE (\%) & AME (MJ/kg) & AMEn $(\mathrm{MJ} / \mathrm{kg})$ \\
\hline & Without & $71.12 \pm 1.29$ & $62.79 \pm 2.06$ & $83.14 \pm 1.83$ & $14.34 \pm 0.21$ & $13.47 \pm 0.20$ \\
\hline \multirow[t]{3}{*}{ Antioxidant } & Natural & $70.75 \pm 1.24$ & $61.52 \pm 2.34$ & $82.64 \pm 1.82$ & $14.34 \pm 0.22$ & $13.47 \pm 0.19$ \\
\hline & Synthetic & $71.20 \pm 1.41$ & $62.24 \pm 2.19$ & $83.52 \pm 1.88$ & $14.38 \pm 0.25$ & $13.52 \pm 0.23$ \\
\hline & Without & $71.06 \pm 0.93$ & $62.75 \pm 1.96$ & $82.79 \pm 1.87$ & $14.41 \pm 0.16$ & $13.53 \pm 0.15$ \\
\hline \multirow[t]{2}{*}{ Heat Treatment } & Dry & $70.88 \pm 1.39$ & $61.74 \pm 1.99$ & $82.96 \pm 1.81$ & $14.35 \pm 0.24$ & $13.49 \pm 0.22$ \\
\hline & Moist & $71.13 \pm 1.58$ & $62.06 \pm 2.65$ & $83.54 \pm 1.88$ & $14.30 \pm 0.26$ & $13.45 \pm 0.23$ \\
\hline \multicolumn{7}{|l|}{$p$ values * } \\
\hline Antioxidant & & 0.35 & 0.06 & 0.17 & 0.69 & 0.53 \\
\hline Heat Treatment & & 0.74 & 0.15 & 0.25 & 0.17 & 0.32 \\
\hline Antioxidant X Heat Treatment & & 0.11 & 0.008 & 0.34 & 0.27 & 0.23 \\
\hline
\end{tabular}

$p^{*}$ significance level at $5 \%$ by ANOVA. Means followed by distinct letters in the column differ significantly by the Tukey test $(p \leq 0.05)$ within each factor. DM- Dry matter; NR- nitrogen retention; EE- ether extract. Natural antioxidant (1000 ppm tocopherols, 250 ppm citric acid and 1000 ppm neem oil); synthetic antioxidant (100 ppm TBHQ (Tertiary Butylhydroquinone), $250 \mathrm{ppm}$ citric acid, and $5000 \mathrm{ppm}$ formaldehyde; dry-heat (with a 1000-W microwave intermittently for $4 \mathrm{~min}$ at an average temperature of $85^{\circ} \mathrm{C}$ ) and moist-heat (conditioning at $90^{\circ} \mathrm{C}$ for approximately 10 seconds followed by $4.75-\mathrm{mm}$ matrix pelletization). 
Table 8 - Interaction between factors for the nitrogen retention coefficient (mean \pm standard deviation).

\begin{tabular}{lccc}
\hline & \multicolumn{3}{c}{ Nitrogen retention coefficient (\%) } \\
\cline { 2 - 4 } Heat treatment & Without & Antioxidant & Sytural \\
\cline { 2 - 4 } & $62.40 \pm 2.11$ & $62.82 \pm 2.36 \mathrm{~A}$ & $63.01 \pm 1.46$ \\
Without & $62.09 \pm 2.57 \mathrm{ab}$ & $60.29 \pm 1.26 \mathrm{Bb}$ & $62.84 \pm 0.89 \mathrm{a}$ \\
Mry & $63.88 \pm 0.77 \mathrm{a}$ & $61.41 \pm 2.63 \mathrm{ABab}$ & $60.88 \pm 3.08 \mathrm{~b}$ \\
\hline
\end{tabular}

Capital letters in the column differ from each other depending on the heat treatment within each antioxidant. Lowercase letters on the line differ from each other as a function of the antioxidant within each heat treatment. Natural antioxidant (1000 ppm tocopherols, $250 \mathrm{ppm}$ citric acid and $1000 \mathrm{ppm}$ neem oil); synthetic antioxidant (100 ppm TBHQ (Tertiary Butylhydroquinone), $250 \mathrm{ppm}$ citric acid, and $5000 \mathrm{ppm}$ formaldehyde; dry-heat (with a $1000-\mathrm{W}$ microwave intermittently for 4 min at an average temperature of $85^{\circ} \mathrm{C}$ ) and moistheat (conditioning at $90^{\circ} \mathrm{C}$ for approximately 10 seconds followed by 4.75 -mm matrix pelletization).

\section{DISCUSSION}

The results of the present study demonstrate that treating rice bran RB with antioxidants does not affect broiler performance. Similarly, Mujahid et al. (2004) did not find a significant effect on broiler performance when evaluating the effect of antioxidants up to 250 ppm in rice bran.

Chae et al. (2002) studied the thermal processes of RB stabilization and suggested that supplementation with rancid rice meal may impair the performance of animals. Their results demonstrated greater RB stabilization through the thermal process, which resulted in better animal performance.

Yasin et al. (2012) and Parveen et al. (2013) evaluating the natural antioxidant in the diet of chickens, depicted that broilers receiving $\alpha$-tocopherol in feed gain higher body weight and better feed conversion efficiency.

Similarly, Rocha (2002) stabilized RB with microwave treatment and observed reduced levels of free fatty acids after four weeks of storage, and Ramezanzadeh et al. (1999) observed lower lipase levels in microwavetreated meal stored for 16 weeks. Previously, Rosniyana et al. (2009) indicated that RB stored for 4 to 6 months could be thermally stabilized by autoclaving and parboiling, respectively.

Farias et al. (2014), testing the stabilization of new, parboiled rice bran and that of RB stored for 180 days in quails, observed that the control diet (without bran) had higher dry matter and mineral digestibility coefficients. However, the AME and AMEn values of the control diet were lower than those of the other treatments containing rice bran.

Mujahid et al. (2003) reported lower fat digestibility values with increased RB storage time, but the magnitude of this effect depended on the level of inclusion in the diet and the thermal processing to which the meal was submitted.
In addition, according to Kurir et al. (2004), the presence of toxic compounds formed during oxidation can damage liver epithelial cells, and changes in the fatty acid composition of the liver can alter organ size due to disorders caused by lipid metabolism. Thus, the lack of variation in liver weight is an indication that the secondary and tertiary products formed during oxidation were not sufficient to affect the organ.

In conclusion, RB, although considered an oxidativeunstable ingredient, showed to be little influenced by the use of antioxidants and storage for 90 days. However, thermally treating this RB proved to be more effective, as demonstrated by the performance responses of the birds. Broilers reared until 28 days of age consuming diets containing $6.5 \%$ of whole RB stabilized by heat treatment showed improved performance, and the use of antioxidants was not necessary.

\section{REFERENCES}

Amad AA, Männer K, Wendler KR, Neumann K, Zentek J. Effects of a phytogenic feed additive on growth performance and ileal nutrient digestibility in broiler chickens. Poultry Science 2011;90:2811-2816.

ASAE- American Society of Agricultural Engineers. Moisture measurementunground grain and seeds. In: Standards. St. Joseph: ASAE; 2000. p. 563.

AOAC. Association of Official Analitical Chemists. Official methods of analysis. $16^{\text {th }}$ ed. Arlington: AOAC; 2000.

AOAC. Association of Official Analitical Chemists. Official methods of analysis. 13 $3^{\text {th }}$ Washington; 1995. 1094p.

Boccard R, Buchter L, Cassels E. Procedures for measuring meat quality characteristics in beef production experiments. Livestock Production Science 1981;8:385-397.

Borazjanizadeh M, Eslami M, Bojarpour M, Chaji M, Fayazi J. The Effect of clove and oregano on economic value of broiler chickens diet under hot weather of Khuzestan. Journal of Animal and Veterinary Advances 2011;10:169-173.

Brunschwiler C, Heine D, Kappeler S, Conde-petit B, Niström L. Direct measurement of rice bran lipase activity for inactivation kinetics and storage stability prediction. Journal of Cereal Science 2013;58:272277. 
Carocho M, Ferreira IC. A review on antioxidants, prooxidants and related controversy: natural and synthetic compounds, screening and analysis methodologies and future perspectives. Food Chemical and Toxicology 2013;51:15-25.

Chae BJ, Leek H, Lee SK. Effects of feeding rancid rice bran on growth performance and chicken meat quality in broiler chicks. AsianAustralian Journal Animal Science 2002;15:266-273.

Chaiyasit W, Elias RJ, Mcclements DJ, Decker EA. Role of physical structures in bulk oils on lipid oxidation. Critical Reviews in Food Science and Nutrition 2007;47:299-317.

Farias NNP, Freitas ER, Xavier RPS, Braz NM, Tavares TCL, Figueiredo CWS, et al., Farelo integral de arroz parboilizado submetido a armazenamento prolongado para alimentação de codornas de corte. Pesquisa Agropecuária Brasileira 2014;49(6):407-415.

Glushenkova Al, Ul'chenko NT, Talipova M, Mukhamedova KHS, Bekker NP, Tolibaev L. Lipids of rice bran. Chemistry of Natural Compounds 1998;34(3):275- 277.

Hafeez A, Männer K, Schieder C, Zentek J. Effect of supplementation of phytogenic feed additives (powdered vs. encapsulated) on performance and nutrient digestibility in broiler chickens. Poultry Science 2016;95:622-629.

Haselmeyer A, Zentek J, Chizzola R. Effects of thyme as a feed additive in broiler chickens on thymol in gut contents, blood plasma, liver and muscle. Journal Science and Food Agriculture 2015;95:504-508.

Karre L, Lopez K, Getty KJK. Natural antioxidants in meat and poultry products. Meat Science 2013;94:220-227.

Kurir TT, Markotić A, Katalinić V, Bozanić D, Cikes V, Zemunik T, et al., Effect of hyperbaric oxygenation on the regeneration of the liver after partial hepatectomy in rats. Brazilian Journal of Medical and Biological Research 2004;37:1231-1237.

Luna A, Lábaque MC, Zygadlo JA, Marin RH. Effects of thymol and carvacrol feed supplementation on lipid oxidation in broiler meat. Poultry Science 2010;89:366-370.

Maragno VP, Kuhn RC. Estabilidade do farelo de arroz sob diferentes tratamentos: micro-ondas, peletização e desengorduramento. UNOPAR Cientifica Ciências Biológicas e da Saúde 2013;15(1):47-53.

Matterson LD, Potter LM, Stutz MW. The metabolizable energy of feed ingredients for chickens. Storrs: The University of Connecticut, Agricultural Experiment Station; 1965. 11p.

Mujahid A, Haq IUL, Asif M, Gilani AH. Effect of different levels of rice bran processed by various techniques on performance of broiler chicks. British Poultry Science 2004;45(3):395-399.
Oliveira MG de C, Bassinello PZ, Lobo VL da S, Rinaldi MM. Stability and microbiological quality of rice bran subjected to different heat treatments. Ciência e Tecnologia de Alimentos 2012;32:725-732.

Parveen R, Asghar A, Anjum FM, Khan MI, Arshad MS, Yasmeen A. Selective deposition of dietary alpha-lipoic acid in mitochondrial fraction and its synergistic effect with alpha-tocoperhol acetate on broiler meat oxidative stability. Lipids in Health and Diseases 2013;12:52.

Pasha TN, Khattakl FM, Khan DR, JabBAR MA. Effect of storage time on the rancidity and metabolizable energy of rice polishing in poultry. AsianAustralian Journal Animal Science 2008;21(3):420-425.

Pestana VR, Zambiazi RC, Mendonça CRB, Bruscatto MH, Ramos GR. Influencia del processado industrial sobre las características quimico-fisicas y contenido en lípidos y antioxidantes del salvado de arroz. Grasas y Aceites 2009;60:184-193

Ramezanzadeh FM, Rao RM, Windhauser M, Prinyawiwatkul W, Tulley $\mathrm{R}$, Marshall WE. Prevention of hydrolytic rancidity in rice bran during storage. Journal of Agricicultural and Food Chemistry 1999;47:30503052.

Rocha CA. Efeito do tratamento por microondas do arroz recém colhido no rendimento de grãos inteiros, na qualidade de cozimentos e na estabilização do farelo [thesis]. Campinas (SP): Universidade Estadual de Campinas; 2002.

Rosniyana A, Hashifah MA, Shariffah Norin SA. Nutritional content and storage stability of stabilized rice bran - MR 220. Journal of Tropical Agriculture and Food Science 2009;37(2):163-170.

Rostagno HS, Albino LFT, Donzele JL, Gomes PC, Oliveira R F, Lopes D C, et al., Tabelas brasileiras para aves e suínos: composição de alimentos e exigências nutricionais. $3^{a}$ ed. Viçosa: UFV; 2011. 252 p.

Sakomura NK, Rostagno HS. Métodos de pesquisa em nutrição de monogástricos. Jaboticabal: Funep, 2007. 283p.

SAS Institute. System for microsoft windows. Release 9.2 [CD-ROM]. Cary; 2002-2008.

Waheed A, Ahmad T, Yousaf A, Zaefr IJ. Effect of various levels of fat and antioxidant on the quality of broiler rations stored at high temperature for different periods. Pakistan Veterinary Journal 2004;24(2):70-75.

Yasin M, Asghar A, Anjum F, Butt M, Khan M, Arshad M, et al., Oxidative stability enhancement of broiler bird meats with a-lipoic acid and $\alpha$-tocopherol acetate supplemented feed. Food Chemiostry 2012:131:768-773. 